\title{
Acquisition of iron from citrate by Pseudomonas aeruginosa
}

\author{
Rita A. Harding and Paulette W. Royt* \\ Biology Department, George Mason University, Fairfax, VA 22030-4444, USA
}

(Received 31 October 1989; revised 19 April 1990; accepted 24 May 1990)

\begin{abstract}
Transport of $\left[{ }^{14} \mathrm{C}\right]$ citrate, ferric $\left[{ }^{14} \mathrm{C}\right]$ citrate and $\left[{ }^{55} \mathrm{Fe}\right]$ ferric citrate into Pseudomonas aeruginosa grown in synthetic media containing citrate, succinate, or succinate and citrate as carbon and energy sources was measured. Cells grown in citrate-containing medium transported radiolabelled citrate and iron, whereas the succinate-grown cells transported iron but not citrate. Binding studies revealed that isolated outer and inner membranes of citrategrown cells contain a citrate receptor, absent from membranes of succinate-grown cells. $\left.\right|^{55} \mathrm{Fe} \mid \mathrm{Ferric}$ citrate bound to the isolated outer membranes of each cell type. The failure of citrate to compete with this binding suggests the presence of a ferric citrate receptor on the outer membranes of each cell type. Citrate induced the synthesis of two outer-membrane proteins of 41 and $19 \mathrm{kDa}$. A third protein of $17 \mathrm{kDa}$ was more dominant in citrate-grown cells than in succinate-grown cells.
\end{abstract}

\section{Introduction}

Micro-organisms have evolved intricate systems to sequester iron from insoluble complexes and other ironcontaining compounds. The low-affinity systems operate in the presence of high levels of environmental iron. Better understood are the high-affinity transport systems which are comprised of low-molecular-mass (600 to $1000 \mathrm{Da}$ ) iron-chelating compounds, termed siderophores, and membrane receptor proteins specific for the iron-bound siderophore, i.e. the ferrisiderophore. Siderophores are secreted into the environment of the cell, where they bind $\mathrm{Fe}^{3+}$. Once iron-bound, the siderophore delivers iron to a specific cell surface receptor, after which internalization of either intact ferrisiderophore or only the iron occurs.

Some micro-organisms have also been shown to take iron directly from naturally occurring iron-binding acids. Such 'functional siderophores' include pyruvate, malate, isocitrate and citrate (Archibald \& DeVoe, 1980). Iron is transported by citrate into the fungus Neurospora crassa (Winkelmann, 1979), the Gram-positive bacterium Mycobacterium smegmatis (Messenger \& Ratledge, 1982), and the Gram-negative bacteria Neisseria meningitidis (Archibald \& DeVoe, 1980), Escherichia coli (Frost \& Rosenberg, 1973) and Pseudomonas aeruginosa (Cox,

\footnotetext{
Abbreviations: KDO, 2-keto-3-deoxyoctonic acid (3-deoxy-D-manno2-octulosonic acid); TEMED, $N, N, N^{\prime}, N^{\prime}$-tetramethylethylenediamine.
}

1980). The iron-citrate uptake systems of $E$. coli (Wagegg \& Braun, 1981) and of $N$. meningitidis (Simonson et al., 1981) contain outer-membrane receptors that recognize extracellular ferric citrate. Neither of these organisms, however, used citrate as a carbon and energy source. Both organisms use citrate only as an iron shuttle, in that dissociation of the metal and ligand occurs at the cell envelope followed by entry of only the iron into the cell (Hussein et al., 1981; Simonson et al., 1981). P. aeruginosa, however, does use citrate as a carbon and energy source, leading us to explore the mechanism of iron transport via citrate into these cells. Does the intact ferric citrate complex enter the cell via a distinct transport system to provide the cell with both iron and citrate? Or, do two separate transport systems exist, one which transports iron following its removal from citrate at the cell surface, and another which transports uncomplexed citrate? It is also possible that more than one mechanism for iron transport via citrate exists in this organism.

Using $P$. aeruginosa grown in synthetic media containing citrate, succinate, or citrate and succinate as carbon sources, transport studies using radiolabelled citrate and ferric citrate were performed, and the outer-membrane protein profiles of these cells were examined to ascertain if specific proteins are induced by citrate. 


\section{Methods}

Organism and culture conditions. All experiments were done using $P$. aeruginosa ATCC 15692 . Cultures were shaken at 150 r.p.m. at $30^{\circ} \mathrm{C}$ in a New Brunswick rotatory shaker. The succinate synthetic medium (SSM) used was that of Meyer \& Abdallah (1978), and contained $34 \mathrm{~mm}$-succinic acid. The citrate synthetic medium (CSM) was prepared as SSM with $10 \mathrm{~g}$ sodium citrate per litre ( $34 \mathrm{mM})$ substituted for succinic acid. Succinate/citrate synthetic medium (SSM/CSM) contained both $34 \mathrm{~mm}$-succinic acid and $34 \mathrm{~mm}$-sodium citrate. The remaining ingredients were the same as in SSM. When mentioned, these media were supplemented with $6 \cdot 2,31$ or $62 \mu \mathrm{M}$-iron. Also, SSM was supplemented with sodium citrate to 16,140 or $636 \mu \mathrm{M}$. Culture flasks were routinely rinsed with $1 \mathrm{M}-\mathrm{HCl}$ before the final rinses with deionized water. Growth was monitored by measuring $\mathrm{OD}_{600}$ using a Gilford Response UV/Vis spectrophotometer.

Membrane preparation. Outer membranes of late-exponential phase cells were separated from inner membranes using a modification of the method of Mizuno \& Kageyama (1978). By this method, spheroplasts are formed upon incubating cells in the presence of lysozyme and EDTA. Released outer membranes are separated from the membranes of spheroplasts by centrifugation. In our procedure, after incubating washed cells in the presence of sucrose, Tris $/ \mathrm{HCl} \mathrm{pH} 7.8$ and 18 or $36 \mathrm{mg}$ lysozyme (Sigma) as described by Mizuno \& Kageyama (1978), $1 \mathrm{mg}$ RNAase (Sigma) and $1 \mathrm{mg}$ DNAase I (Sigma) were added to the cell suspension at $30 \mathrm{~min}$. Also, crude, washed outer and spheroplast membranes were not dialysed against EDTA, but applied directly to discontinuous sucrose gradients consisting of $1 \mathrm{ml}$ amounts of $75 \%$, $70 \%, 64 \%$ and $58 \%(w / v)$ sucrose. Following centrifugation for $2 \mathrm{~h}$ at $189000 \mathrm{~g}$ in a Beckman $50.1 \mathrm{SW}$ rotor, the membrane fractions were washed twice in $0.1 \mathrm{M}$-Tris/ $\mathrm{HCl} \mathrm{pH} 7.8$ before gel electrophoresis. For binding studies, membranes were washed instead in 0.1 M-MOPS buffer $\mathrm{pH} 7 \cdot 2$. A $60 \mathrm{mM}$-potassium phosphate buffer, $\mathrm{pH} 7 \cdot 2$, was used to wash membranes before measurements of 2-keto-3-deoxyoctonate (KDO) and enzyme activity were made. The crude outer-membrane fraction separated into one large band at the top of the gradient, while the crude inner membranes separated into four distinct bands. The third band from the top of the gradient was chosen for binding studies as it had significant levels of cytoplasmic membrane markers and the lowest KDO concentration of the four bands.

Analytical procedures. Membrane fractions were tested for the outer membrane marker KDO according to the procedure of Weissbach \& Hurwitz (1959). Assays for NADH oxidase and malate dehydrogenase were performed by the methods of Mizuno \& Kageyama (1978), and protein was determined by the Lowry method, using bovine serum albumin as standard. Pyoverdine was measured spectrophotometrically at $400 \mathrm{~nm}$ in cell-free spent media (Meyer et al., 1987).

SDS-PAGE. This was done by the system of Laemmli (1970) using a Bio-Rad model 220 dual vertical slab electrophoresis cell. Separating gels contained $12 \%(\mathrm{w} / \mathrm{v})$ acrylamide (Bio-Rad), $0.32 \%$ bis-acrylamide (Bio-Rad), $0.1 \%$ SDS (Bio-Rad), 0.025\% TEMED (Bio-Rad) and $70 \mathrm{~mm}-\mathrm{NaCl}$ in $0.375 \mathrm{M}$-Tris $/ \mathrm{HCl}, \mathrm{pH} 8.8$. The separating gel was overlaid with a stacking gel consisting of $3 \%$ acrylamide, $0.08 \%$ bisacrylamide, $0.1 \%$ SDS and $0.05 \%$ TEMED in $0.125 \mathrm{M}-\mathrm{Tris} / \mathrm{HCl}$, pH 6.8. Electrophoresis was carried out at $30 \mathrm{~mA}$ per slab $(14 \mathrm{~cm} \times 15 \mathrm{~cm} \times 1.5 \mathrm{~mm})$, at $4{ }^{\circ} \mathrm{C}$. The electrode buffer consisted of $0.033 \mathrm{M}$-Tris $/ \mathrm{HCl}, 0.256 \mathrm{M}$-glycine and $0.1 \% \mathrm{SDS}$. Gels were stained in a solution of $0.125 \%(\mathrm{w} / \mathrm{v})$ Coomassie brilliant blue R-250 (Bio-Rad), $50 \%(\mathrm{v} / \mathrm{v})$ methanol and $10 \%(\mathrm{v} / \mathrm{v})$ glacial acetic acid. Following destaining in $50 \%(\mathrm{v} / \mathrm{v})$ methanol and $10 \%(\mathrm{v} / \mathrm{v})$ acetic acid, gels were photographed.
Molecular mass standards (Sigma) used were egg white lysozyme $(14.4 \mathrm{kDa})$, carbonic anhydrase $(29 \mathrm{kDa})$, egg albumin $(45 \mathrm{kDa})$, bovine serum albumin $(66 \mathrm{kDa})$, phosphorylase $b(97.4 \mathrm{kDa})$ and $\beta$ galactosidase $(116 \mathrm{kDa})$.

Metabolic studies. SSM- and SSM/CSM-grown cells were washed once with $0.1 \mathrm{M}$-MOPS buffer $\mathrm{pH} 7.2$, and resuspended in this buffer to an $\mathrm{OD}_{600}$ of approximately 1.0 . Fifty millilitres of the suspension was placed in a $250 \mathrm{ml}$ biometer flask (Bellco). The sidearm of the flask contained $5 \mathrm{ml}$ phenethylamine (Kodak) to trap radiolabelled $\mathrm{CO}_{2}$. The sidearm stopper held a $1 \mathrm{ml}$ tuberculin syringe with a $38.1 \mathrm{~mm}$ hypodermic needle and Tygon tubing to withdraw samples for ${ }^{14} \mathrm{CO}_{2}$ analysis. Flasks containing the cell suspension were placed in a $30^{\circ} \mathrm{C}$ incubator shaker. After $20 \mathrm{~min}, 2.5 \mu \mathrm{Ci}\left[1,5-{ }^{14} \mathrm{C}\right]$ citric acid (specific activity $64.7 \mathrm{Ci} \mathrm{mol}^{-1}, 2394 \mathrm{GBq} \mathrm{mmol}{ }^{-1}$; New England Nuclear) or $2.5 \mu \mathrm{Ci}\left[1,4^{-14} \mathrm{C}\right]$ succinic acid (specific activity $20.5 \mathrm{Ci} \mathrm{mol}^{-1}$, $758.5 \mathrm{GBq} \mathrm{mol}^{-1}$; ICN Radiochemicals) was added. At selected time intervals, $0.1 \mathrm{ml}$ phenethylamine was placed in a scintillation vial, Optifluor scintillation fluid (Packard) added, and the radioactivity of the samples measured in a Packard $300 \mathrm{CD}$ liquid scintillation counter. Quench analysis was done by the external standards channel ratio method.

Transport assays. Late-exponential-phase cells were used in all transport assays. To examine transport of $\left[{ }^{14} \mathrm{C}\right]$ citrate and ferric $\left[{ }^{14} \mathrm{C}\right]$ citrate, cells were washed twice at room temperature with growth medium without a carbon source, $\mathrm{pH} 7 \cdot 2$. Cells were resuspended in medium without a carbon source and incubated at $30^{\circ} \mathrm{C}$ for $15 \mathrm{~min}$. To examine transport of $\left[{ }^{55} \mathrm{Fe}\right]$ ferric citrate, cells were instead washed, resuspended, and incubated as above in MOPS buffer to prevent the formation of $\left.{ }^{55} \mathrm{Fe}\right]$ ferric phosphate in the growth medium. When indicated, cells for $\left.{ }^{55} \mathrm{Fe}\right]$ ferric citrate transport studies were instead washed and resuspended in MOPS buffer deferrated using Chelex 100 (Bio-Rad) in a batch process. [ $\left.{ }^{55} \mathrm{Fe}\right] \mathrm{Ferric}$ citrate transport was determined at least four times for each cell type. Succinic acid, to $50 \mu \mathrm{M}$, was added to all suspension of cells grown in SSM and SSM/CSM $15 \mathrm{~s}$ before addition of radiolabelled substrate. When indicated, fluorocitrate, to $100 \mu \mathrm{M}$, was added $5 \mathrm{~min}$ before addition of substrate. $\left[{ }^{14} \mathrm{C}\right] \mathrm{Citric}$ acid and ferric $\left[{ }^{14} \mathrm{C}\right]$ citrate were both used to a final concentration of $50 \mu \mathrm{M}$-citrate. With each of these substrates, the specific activity used was $0.2 \mu \mathrm{Ci} \mu \mathrm{mol}^{-1}\left(7.4 \mathrm{kBq} \mu \mathrm{mol}^{-1}\right)$. When using ferric $\left[{ }^{14} \mathrm{C}\right]$ citrate, the ratio of citrate to iron was $200: 1$. The substrate $\left[{ }^{55} \mathrm{Fe}\right]$ ferric citrate was used to a final concentration of 1.25 or $2.5 \mu \mathrm{M}$ iron, and a specific activity of 100.8 or $50.4 \mu \mathrm{Ci} \mu \mathrm{mol}^{-1}(3.73$ or $1.86 \mathrm{MBq} \mu \mathrm{mol}^{-1}$ ), respectively. Here, the ratio of citrate to iron was $100: 1,200: 1$ or $400: 1$, as mentioned. The total volume of cell suspension was $5 \mathrm{ml}$. Samples $(0.5 \mathrm{ml})$ were withdrawn at set time intervals, and added to $5 \mathrm{ml}$ cold MOPS on a Metricel GA-6 filter, porosity $0.45 \mu \mathrm{m}$. The cells were washed twice with $3 \mathrm{ml}$ cold MOPS. The filters were placed in liquid scintillation vials, and radioactivity determined as above.

Binding assays. Outer and inner membranes were collected from cells as described above. Following the final washing in MOPS buffer, outer and inner membranes were resuspended in this buffer to 600 and $560 \mu \mathrm{g}$ protein $\mathrm{ml}^{-1}$, respectively. To $0.5 \mathrm{ml}$ samples was added $0.0125 \mu \mathrm{Ci}$ $\left[{ }^{14} \mathrm{C}\right.$ citric acid $\left(0 \cdot 1 \mu \mathrm{Ci} \mu \mathrm{mol}^{-1}, 3.7 \mathrm{kBq} \mu \mathrm{mol}^{-1}\right)$ or $0.06 \mu \mathrm{Ci}\left[{ }^{55} \mathrm{Fe}\right] \mathrm{fer}-$ ric vitrate $\left(24 \mu \mathrm{Ci} \mathrm{mol}^{-1}, 888 \mathrm{kBq} \mu \mathrm{mol}^{-1}\right)$ containing a $200: 1,400: 1$ or 600:1 citrate to iron ratio. After $15 \mathrm{~min}$ at room temperature, each suspension was added to $1.0 \mathrm{ml}$ MOPS buffer on a $0.2 \mu \mathrm{m}$ pore-size MF-Millipore filter. The membranes were washed twice with $2 \mathrm{ml}$ MOPS buffer, and the radioactivity on the filter measured. Radiolabelled substrate was filtered as above in the absence of membranes, and the amount of activity was subtracted from that of each filter containing membranes. 


\section{Results}

\section{Growth and metabolic studies}

Addition of $16 \mu \mathrm{M}$-citrate to succinate-containing media stimulated growth of $P$. aeruginosa (Fig. 1a). Higher concentrations, 140 and $636 \mu \mathrm{M}$, of citrate added to SSM also increased the growth rate. In the absence of added citrate, pyoverdine, the major exogenous siderophore of this organism (Ankenbauer et al., 1985), was released into the growth medium during the early exponential
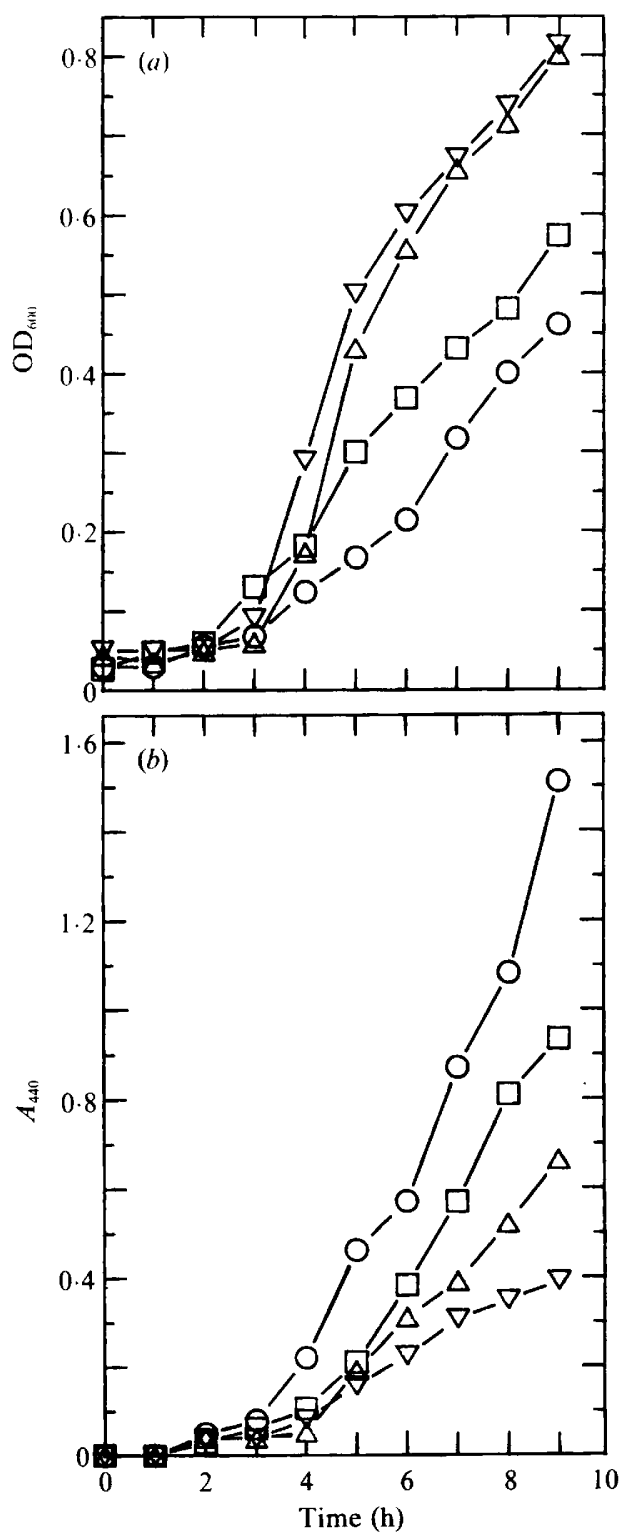

Fig. 1. (a) Growth $\left(\mathrm{OD}_{600}\right)$ and $(b)$ pyoverdine production, measured as the $A_{400}$ of the spent culture medium, of $P$. aeruginosa in various media. Cells were grown in SSM with no added sodium citrate $(O)$, and in SSM with $16 \mu \mathrm{M}$-sodium citrate $(\square), 140 \mu \mathrm{M}$-sodium citrate $(\triangle)$ and $636 \mu \mathrm{M}$-sodium citrate $(\nabla)$. phase of growth (Fig. $1 b$ ), but addition of increasing concentrations of citrate to SSM decreased the amount of pyoverdine detected in the spent medium during the exponential phase of growth. Also, addition of $31 \mu \mathrm{M}$ $\mathrm{FeCl}_{3}$ to SSM delayed the appearance of pyoverdine until the stationary phase, and in both CSM and SSM/CSM cultures, pyoverdine synthesis was repressed in low- as well as high-iron conditions at all stages of growth (data not shown).

To determine if cells grown in SSM/CSM metabolized citrate, succinate or both substrates, cells were incubated with $\left[{ }^{14} \mathrm{C}\right]$ citrate and with $\left[{ }^{14} \mathrm{C}\right]$ succinate and the evolution of radiolabelled $\mathrm{CO}_{2}$ was determined. Midexponential-phase cells metabolized succinate at a greater rate than citrate (Fig. $2 a$ ). Within $2 \mathrm{~h}$, the cells metabolized 4.3 times as much succinate as citrate. Lateexponential-phase cells metabolized citrate at a rate comparable to that of mid-exponential-phase cells (Fig. $2 b$ ). The addition of unlabelled succinate to the incubation mixture of the late-exponential-phase cells failed to significantly stimulate citrate metabolism by these cells. Also, mid-exponential-phase SSM cells failed to metabolize significant levels of radiolabelled citrate over a $1 \mathrm{~h}$ period (data not shown).

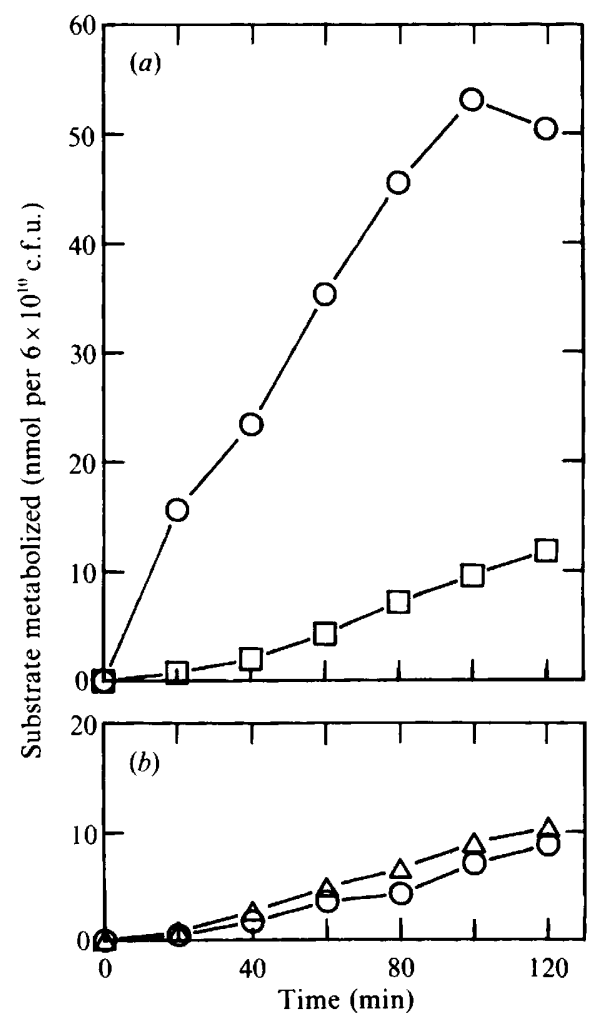

Fig. 2. $\left[{ }^{14} \mathrm{C}\right]$ Succinate and $\left[{ }^{14} \mathrm{C}\right]$ citrate metabolism by cells grown in SSM/CSM. (a) Metabolism of $\left[{ }^{14} \mathrm{C}\right]$ succinate $(O)$ and of $\left[{ }^{14} \mathrm{C}\right]$ citrate ( $\square$ ) by mid-exponential-phase cells. (b) Metabolism of $\left[{ }^{14} \mathrm{C}\right] c i t r a t e$ by late-exponential-phase cells in the absence of succinate $(O)$ and in the presence of equimolar succinate $(\triangle)$. Metabolism of substrate was measured by the evolution of ${ }^{14} \mathrm{CO}_{2}$. 


\section{Transport studies}

Transport of $\left[{ }^{14} \mathrm{C}\right]$ citrate into citrate-grown cells was measured in the presence of fluorocitrate, an effective inhibitor of aconitase in Pseudomonas (Lawford \& Williams, 1971). Preliminary studies measuring the evolution of ${ }^{14} \mathrm{CO}_{2}$ from $\left[{ }^{14} \mathrm{C}\right]$ citrate given to these cells revealed that incubation with $100 \mu \mathrm{M}$-fluorocitrate for 10 min reduced the evolution of radiolabelled $\mathrm{CO}_{2}$ by approximately $60 \%$. This partial blockage of citrate metabolism allowed a more accurate determination of citrate transport.
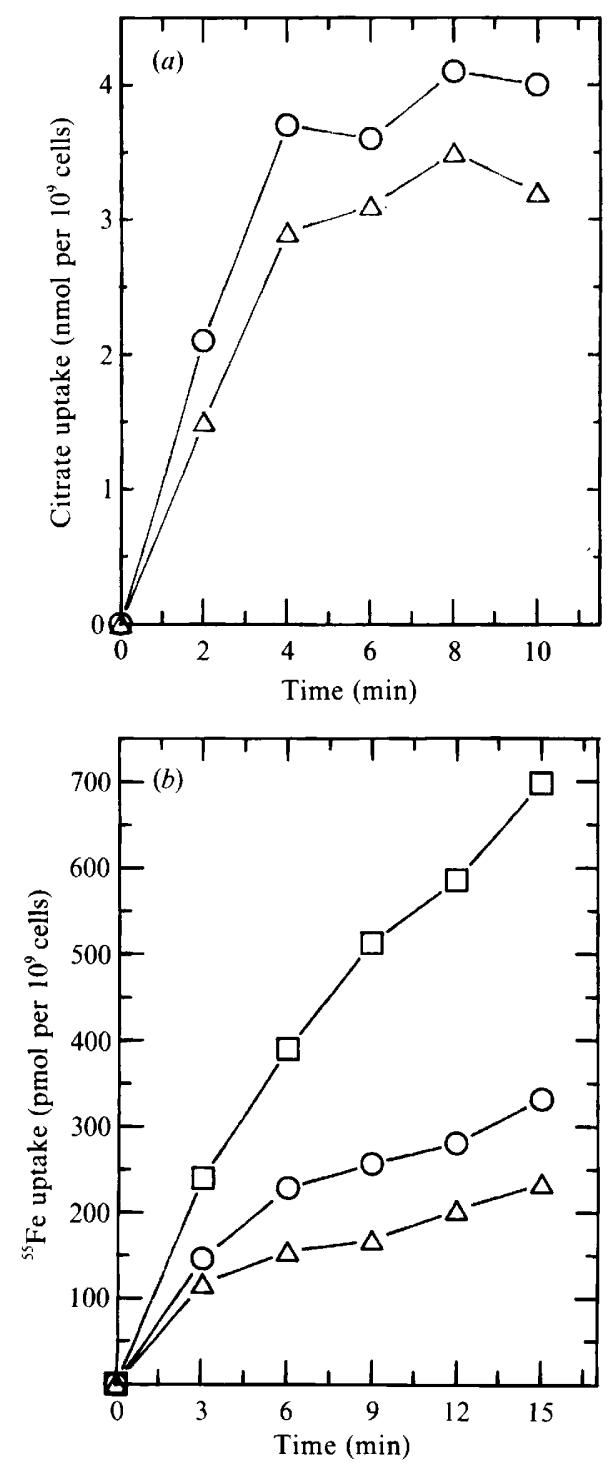

Fig. 3. Transport of citrate and iron via citrate into citrate (CSM)grown cells. (a) Transport of $\left[{ }^{14} \mathrm{C}\right]$ citrate $(O)$ and ferric $\left[{ }^{14} \mathrm{C}\right]$ citrate $(\triangle)$ in the presence of $100 \mu \mathrm{M}$-fluorocitrate. (b) Transport of $\left.{ }^{55} \mathrm{Fe}\right] \mathrm{ferric}$ citrate with a citrate to iron ratio of $200: 1$ (1.25 $\mu \mathrm{M}$-iron) (O), 400:1 (1.25 $\mu \mathrm{M}$-iron) $(\triangle)$ and $100: 1(2.5 \mu \mathrm{M}$-iron) $(\square)$.
When exposed to either $\left[{ }^{14} \mathrm{C}\right]$ citric acid or ferric $\left[{ }^{14} \mathrm{C}\right]$ citrate (200:1 citrate to iron ratio), citrate-grown cells accumulated citrate (Fig. $3 a$ ). However, from our findings with the ferrated complex, we cannot conclude that iron-bound citrate is entering the cell. Rather, unbound citrate of this substrate sample might instead be entering the cell. When CSM-grown cells were incubated in the presence of $\left[{ }^{55} \mathrm{Fe}\right]$ ferric citrate, radiolabelled iron did enter the cell (Fig. $3 b$ ), but increasing the ratio of citrate to iron from $200: 1$ to $400: 1$ reduced the initial rate of ${ }^{55} \mathrm{Fe}$ uptake and the total accumulation of ${ }^{55} \mathrm{Fe}$ in the cells at $15 \mathrm{~min}$. Also, a twofold increase in iron concentration resulted in a greater rate of uptake and total accumulation over this time period.

Succinate-grown cells did not transport uncomplexed citrate or citrate complexed to iron (Fig. 4a). These cells did, however, transport ${ }^{55} \mathrm{Fe}$ bound to unlabelled citrate (Fig. $4 b$ ), with more iron uptake occurring with the higher iron concentration. Also, cells washed and resuspended in deferrated MOPS buffer transported
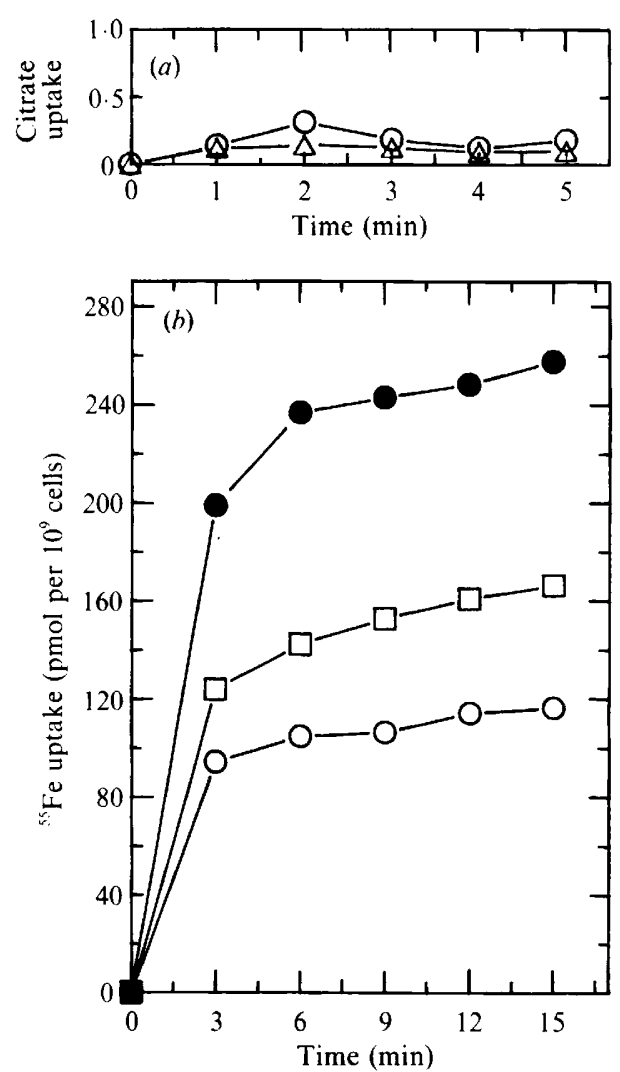

Fig. 4. Citrate and iron transport via citrate into succinate (SSM)grown cells. (a) Transport of $\left[{ }^{14} \mathrm{C}\right]$ citrate $(\mathrm{O})$ and ferric $\left[{ }^{14} \mathrm{C}\right]$ citrate $(\triangle)$, expressed as nmol citrate per $10^{9}$ cells. $(b)$ Transport of $\left[{ }^{55} \mathrm{Fe}\right]$ ferric citrate by cells resuspended in MOPS buffer and exposed to a citrate to iron ratio of $200: 1$ (1.25 $\mu \mathrm{M}$-iron) (O) and 100:1 (2.5 $\mu \mathrm{M}$-iron) ( $\square$ ). Cells were also washed and resuspended in deferrated MOPS buffer and exposed to a $200: 1$ ratio (1.25 $\mu \mathrm{M}$-iron) of citrate to iron ( $)$. 
more radiolabelled iron when exposed to a $200: 1$ ratio of citrate to iron than did cells washed and resuspended in MOPS buffer containing contaminating iron.

Cells grown in medium containing both succinate and citrate accumulated ${ }^{14} \mathrm{C}$ when incubated in the presence of $\left[{ }^{14} \mathrm{C}\right]$ citrate or ferric $\left[{ }^{14} \mathrm{C}\right]$ citrate (Fig. $5 a$ ). These cells also accumulated ${ }^{55} \mathrm{Fe}$ from $\left[{ }^{55} \mathrm{Fe}\right]$ ferric citrate (Fig. $5 b$ ), and cells exposed to substrate with a citrate to iron ratio of $400: 1$ accumulated less radioactivity than did cells incubated with substrate at a 200:1 ratio. Also, cells resuspended in deferrated buffer transported more
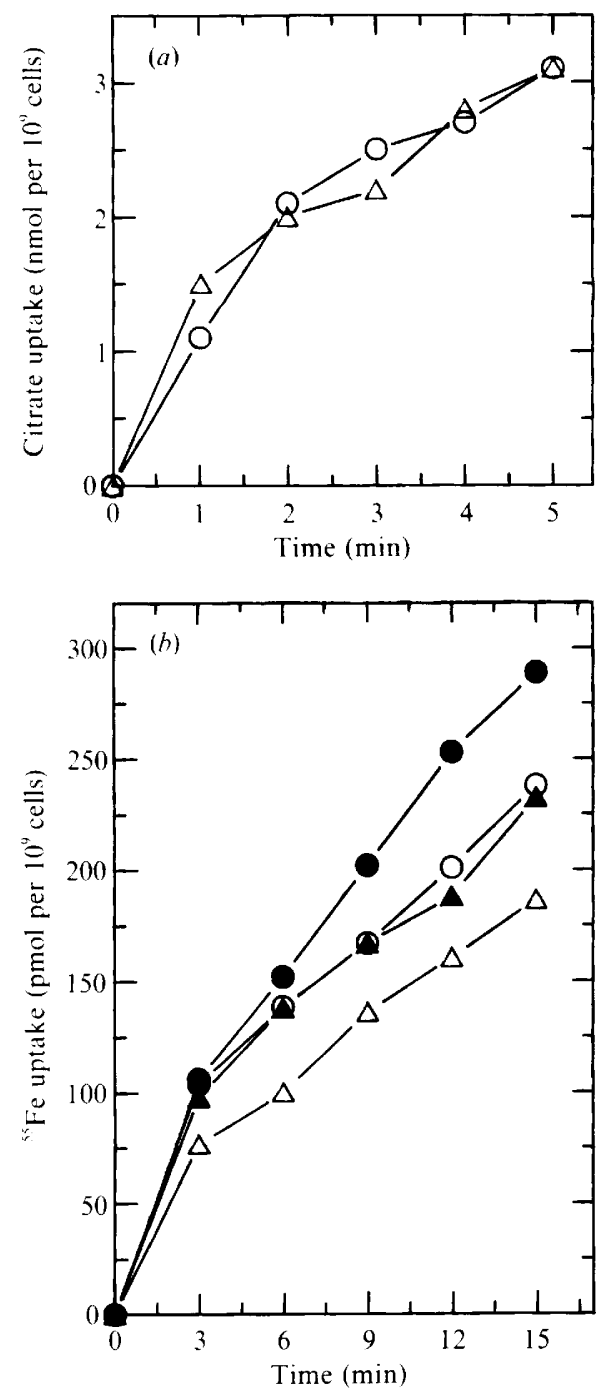

Fig. 5. Transport of citrate and iron via citrate into succinate/citrate (SSM/CSM)-grown cells. (a) Transport of $\left[{ }^{14} \mathrm{C}\right]$ citrate $(O)$ and ferric $\left[{ }^{14} \mathrm{C}\right]$ citrate $(\triangle)$ in the presence of $100 \mu \mathrm{M}$-fluorocitrate. $(b)$ Transport of $\left.{ }^{55} \mathrm{Fe}\right] \mathrm{ferric}$ citrate in the presence of a 200:1 (1.25 $\mu \mathrm{M}$-iron) citrate to iron ratio in MOPS $(O)$ and in deferrated MOPS $(O)$, and in the presence of a $400: 1$ (1.25 $\mu \mathrm{M}$-iron) citrate to iron ratio in MOPS $(\triangle)$ and deferrated MOPS $(\boldsymbol{\Lambda})$. radiolabelled iron than did cells resuspended in buffer containing trace levels of iron.

\section{SDS-PAGE of isolated membranes}

Outer-membrane protein profiles of cells grown in SSM, CSM and SSM/CSM with no added iron and in these media containing $31 \mu \mathrm{M}-\mathrm{FeCl}_{3}$ are shown in Fig. 6 .

The outer membranes of cells grown in iron-poor SSM contained three high-molecular-mass proteins, of 94,87 and $79 \mathrm{kDa}$. The addition of iron to this medium resulted in a decrease in intensity of these three bands. Prominent bands of 14 and $43 \mathrm{kDa}$ were consistently present in these cells grown with and without added iron.

Outer-membrane protein profiles of cells grown in CSM without added iron did not show the highmolecular-mass bands seen in the preparations from SSM-grown cells. Two additional proteins, however, appeared in the profiles of the CSM-grown cells, one of $41 \mathrm{kDa}$ and the other of $19 \mathrm{kDa}$. Also, a $17 \mathrm{kDa}$ protein was greater in intensity in these membranes than in the membranes of SSM-grown cells. The $43 \mathrm{kDa}$ protein which was intense in SSM-grown cells was less intense in CSM-grown cells. The addition of iron to CSM did not change the outer-membrane protein profile.

Similar outer-membrane protein profiles were seen for cells grown in SSM/CSM in both the presence and absence of added iron. The high-molecular-mass proteins seen in the outer membranes of cells grown in SSM without added iron were repressed in these cells as they were in CSM-grown cells. The $43 \mathrm{kDa}$ protein which was dominant in SSM-grown cells was also dominant in $\mathrm{SSM} / \mathrm{CSM}$-grown cells. The $41 \mathrm{kDa}$ protein which appeared in CSM-grown cells appeared in SSM/CSMgrown cells as a very thin band. The intensity of the $17 \mathrm{kDa}$ protein was greater than in SSM-grown cells, but not as great as in CSM-grown cells. The $19 \mathrm{kDa}$ protein which appeared in CSM-grown cells but not in SSMgrown cells was evident in SSM/CSM-grown cells at even greater intensity than in CSM-grown cells. The $14 \mathrm{kDa}$ protein was present in these profiles as in the other two cell types.

When increasing concentrations of citrate were added to SSM with no added iron, the bands representing the high-molecular-mass outer-membrane proteins $(94,87$ and $79 \mathrm{kDa}$ ) faded (Fig. 7). With $16 \mu \mathrm{M}$ added citrate, the $94 \mathrm{kDa}$ protein was repressed, and at higher concentrations of citrate, the 87 and $79 \mathrm{kDa}$ proteins were also repressed. Although not as prominent as in CSM- and SSM/CSM-grown cells, the $19 \mathrm{kDa}$ protein was discernible in the membranes of cells grown in the presence of $140 \mu \mathrm{M}$ - and $636 \mu \mathrm{M}$-sodium citrate. Also, the $41 \mathrm{kDa}$ protein appeared as a thin band in the membranes of 


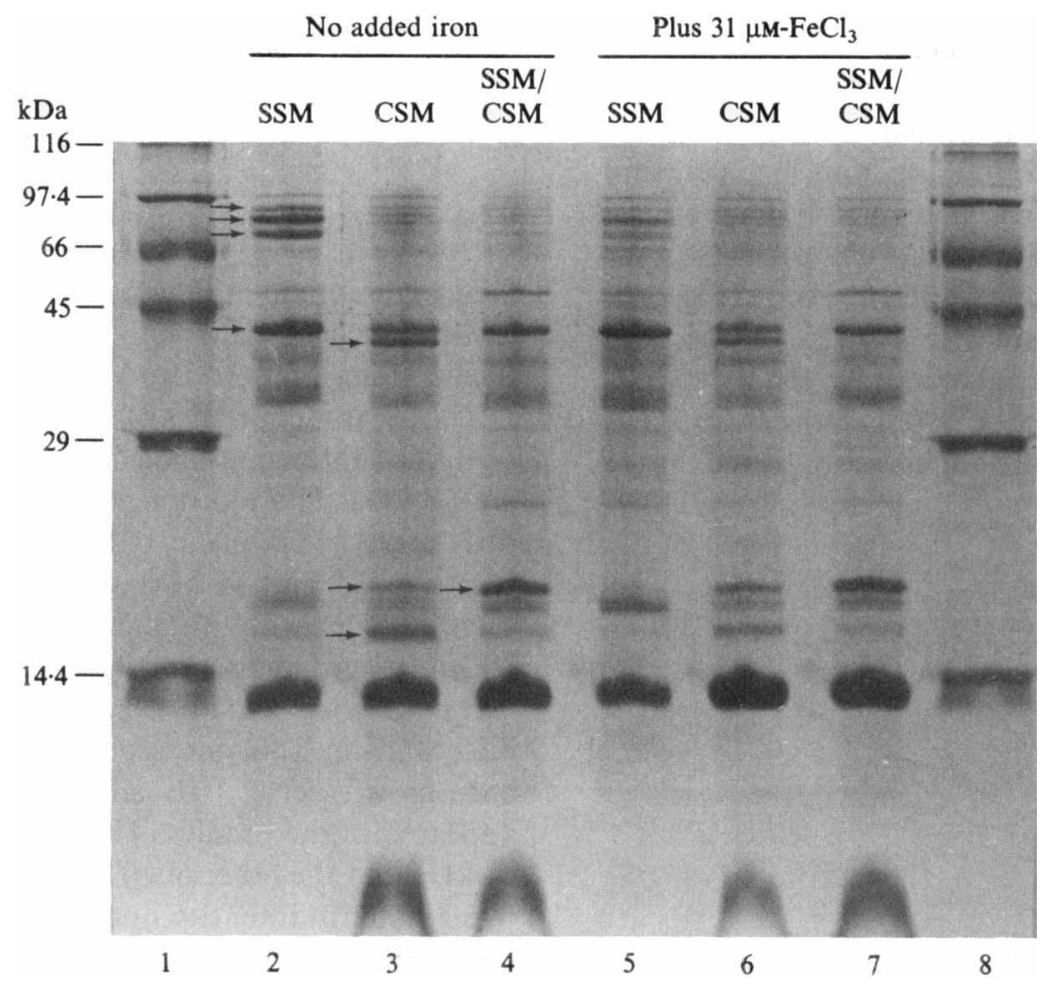

Fig. 6. A comparison of outer-membrane proteins of $P$. aeruginosa grown in SSM, CSM and SSM/CSM, each containing no added iron or $31 \mu \mathrm{M}-\mathrm{FeCl}_{3}$. Lanes 1 and 8 contain molecular mass standards. Lanes 2-7 contain outer membrane proteins of cells grown under the conditions indicated above the photograph. The arrows in lane 2 indicate the high-molecular-mass proteins $(94,87$ and $79 \mathrm{kDa})$ which are repressed by iron and by citrate and the $43 \mathrm{kDa}$ protein which is most intense in SSM-grown cells. The arrows in lane 3 indicate the 41 and $19 \mathrm{kDa}$ proteins which appear only in the presence of citrate, and the $17 \mathrm{kDa}$ protein which increases in intensity in citrategrown cells. The arrow in lane 4 indicates the $19 \mathrm{kDa}$ protein which is more intense in SSM/CSM-grown cells than in CSM-grown cells.

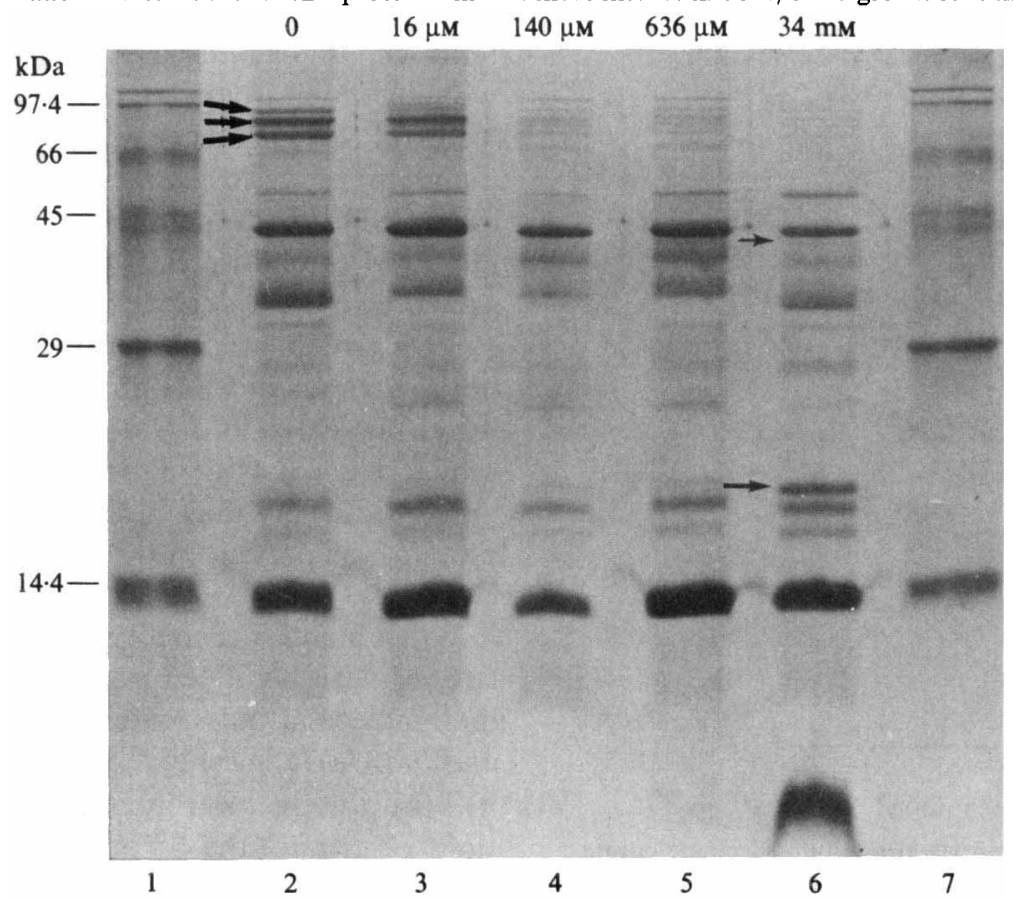

Fig. 7. Effect of citrate on outer-membrane proteins of $P$. aeruginosa grown in SSM containing no added iron. Lanes 1 and 7 contain molecular mass standards. Lanes 2-6 contain outer-membrane proteins of cells grown with the indicated concentration of added sodium citrate. SSM with $34 \mathrm{mM}$-sodium citrate (lane 6) corresponds to SSM/CSM. The arrows in lane 2 indicate the 94,87 and $79 \mathrm{kDa}$ protein bands which fade with increasing concentrations of citrate. The arrows in lane 6 indicate the $19 \mathrm{kDa}$ protein which appears with increasing concentration of citrate, and the $41 \mathrm{kDa}$ protein evident in the membranes of cells grown in medium containing $636 \mu \mathrm{M}$ - or 34 mM-sodium citrate. 
Table 1. Binding of $\left[{ }^{14} \mathrm{C}\right]$ citrate and $\left[{ }^{55} \mathrm{Fe}\right]$ ferric citrate to outer and inner membranes of $P$. aeruginosa

\begin{tabular}{lccc}
\hline & $\begin{array}{c}\text { CSM-grown } \\
\text { cells }\end{array}$ & $\begin{array}{c}\text { SSM-grown } \\
\text { cells }\end{array}$ & $\begin{array}{c}\text { SSM/CSM-grown } \\
\text { cells }\end{array}$ \\
\hline Outer membranes* & 1595 & 225 & 1726 \\
$\left.{ }^{14} \mathrm{C}\right]$ Citrate & & & \\
${ }^{[55}$ Fe]Ferric citrate & 5843 & 11605 & 4568 \\
$\quad$ Citrate/iron ratio 200:1 & 5983 & 12539 & 5331 \\
$\quad$ Citrate/iron ratio 400:1 & 6407 & 12657 & 5965 \\
$\quad$ Citrate/iron ratio 600:1 & & & 1316 \\
Inner membranes $\dagger$ & 1194 & 206 & \\
${ }^{[4]}$ Citrate &
\end{tabular}

* Binding expressed as c.p.m. per $600 \mu \mathrm{g}$ protein.

$\uparrow$ Binding expressed as c.p.m. per $560 \mu \mathrm{g}$ protein.

cells grown in medium supplemented with $636 \mu \mathrm{M}$ - and 34 mM-sodium citrate.

\section{Binding studies}

Outer and inner membranes from CSM- and SSM/CSMgrown cells bound more $\left[{ }^{14} \mathrm{C}\right]$ citrate than did outer and inner membranes isolated from SSM-grown cells (Table 1). The outer membranes from cells grown in SSM, however, had a higher binding capacity for $\left[{ }^{55} \mathrm{Fe}\right]$ ferric citrate than did the outer membranes of cells grown with citrate in the medium. Increasing the ratio of citrate to iron did not influence the binding of radiolabelled iron to the outer membranes of any cell type.

\section{Discussion}

Increasing concentrations of citrate resulted in decreased pyoverdine synthesis by $P$. aeruginosa, yielding preliminary evidence that citrate serves as a functional siderophore for this bacterium. Additionally, cells grown in media containing a high concentration of citrate produced no detectable pyoverdine. Pseudomonas fluorescens grown in citrate-containing medium also fails to produce pyoverdine (Meyer \& Abdallah, 1978), suggesting that citrate, when present in sufficient concentration, supplies iron to the cell, and inhibits pyoverdine synthesis.

Cells grown in CSM or in SSM/CSM transported radiolabelled carbon when incubated with $\left[{ }^{14} \mathrm{C}\right]$ citrate and with ferric $\left[{ }^{14} \mathrm{C}\right]$ citrate. With the latter, the ${ }^{14} \mathrm{C}$ that enters the cells may be from citrate complexed to iron, uncomplexed citrate, or from both sources. Due to the formation of iron hydroxide polymers with bound citrate at low citrate to iron ratios (Spiro et al., 1967a), a 1:1 ratio of citrate to iron could not be used. A ratio of $20: 1$, or greater, prevents polymer formation, and under such conditions the complex consists mainly of ferric dicitrate (Spiro et al., 1967 b). SSM-grown cells failed to transport or metabolize detectable amounts of citrate when incubated with either $\left[{ }^{14} \mathrm{C}\right]$ citrate or ferric $\left[{ }^{14} \mathrm{C}\right]$ citrate. Hence, these cells apparently lack a functional citrate transport system.

Outer membranes of SSM cells grown in iron-poor medium contained high-molecular-mass proteins, as previously reported by Meyer et al. (1979), and the appearance of these proteins was correlated with the synthesis of pyoverdine. Hohnadel \& Meyer (1988) suggested that one of these proteins is the ferripyoverdine receptor. Synthesis of both pyoverdine and highmolecular-mass proteins was repressed by addition of citrate or iron to SSM. Furthermore, the outer-membrane protein profiles of CSM- and SSM/CSM-grown cells, cells which did not synthesize pyoverdine, also showed repression of these high-molecular-mass proteins. Hence, these proteins are not involved in citrate or ferric citrate transport. It has been reported that $E$. coli has an $80 \mathrm{kDa}$ outer-membrane ferric citrate receptor (Braun, 1985).

Two citrate-inducible proteins, of 41 and $19 \mathrm{kDa}$, were detected in the outer membranes of cells grown in CSM. The roles of these two proteins are not known. The absence of the $41 \mathrm{kDa}$ protein from the outer membranes of SSM-grown cells, which do not transport citrate, and its minimal expression in SSM/CSM-grown cells, which metabolize citrate at low levels, indicate a possible role in the uptake of citrate as a carbon and energy source. This suggestion is strengthened by the fact that iron did not affect the apparent concentration of this protein. The $19 \mathrm{kDa}$ protein may also participate in citrate transport, being present in higher amounts in the outer membranes 
of SSM/CSM-grown cells than in those of CSM-grown cells, and absent from membranes of SSM-grown cells. A third protein possibly regulated by citrate is the $17 \mathrm{kDa}$ protein which is found in highest concentrations in the outer membranes of CSM-grown cells.

Each of the three cell types transported ${ }^{55} \mathrm{Fe}$ when incubated with $\left.{ }^{55} \mathrm{Fe}\right] \mathrm{ferric}$ citrate. The fact that SSMgrown cells failed to transport citrate yet sequestered iron from $\left[{ }^{55} \mathrm{Fe}\right]$ ferric citrate indicates that iron is separated from the chelator at the cell surface, with citrate simply shuttling iron to the surface of the cells as occurs in E. coli (Hussein et al., 1981) and N. meningitidis (Simonson et al., 1981). The low level of $\left[{ }^{14} \mathrm{C}\right]$ citrate binding to the inner membranes of SSM-grown cells as compared with that to the inner membranes of CSM- and SSM/CSMgrown cells suggests the absence of significant citrate receptors on the inner membranes of SSM-grown cells, and hence, no significant entry of uncomplexed citrate into the cytoplasm. It is therefore postulated that after ferric citrate passes through the outer membrane of SSMgrown cells, separation of iron and chelator occurs in the periplasm. It is not known whether a similar mechanism of iron uptake by citrate exists in CSM- and SSM/CSMgrown cells. If separation of iron and citrate does occur in the periplasm of these cells, unbound citrate may enter the cell via an inner membrane transport system.

Ferric citrate may bind to an outer membrane receptor before gaining entrance to the periplasm of the cell, or it may enter by passing through a porin channel. Our finding that ${ }^{55} \mathrm{Fe}$ complexed to citrate bound to the outer membranes of $P$. aeruginosa indicates the existence of a membrane receptor present in highest concentrations in SSM-grown cells. As increasing ratios of citrate to iron did not alter the binding of iron to the membranes, there appears to be no competition between citrate and $\left.{ }^{55} \mathrm{Fe}\right] \mathrm{ferric}$ citrate for binding sites to the outer membranes. Hence, ferric citrate probably does not bind to the citrate receptor on CSM- and SSM/CSM-grown cells. However, in all three cell types, an increased concentration of citrate reduced the initial rate of transport of radiolabelled iron and its total accumulation in the cells. Hence, citrate affects iron transport via ferric citrate, but does not affect binding of ferric citrate to the outer membranes of each cell type. We conclude that the outer membranes of each cell type contain a ferric citrate receptor which does not recognize uncomplexed citrate. Since the ferric dicitrate complex and ionic citrate differ in conformation, different specificities would be expected for binding. The inhibitory effect of citrate on iron transport into all three types of cells may be due to dilution of radiolabelled ferric citrate with ferric citrate formed in the suspension buffer. The results of $\left[{ }^{55} \mathrm{Fe}\right]-$ ferric citrate transport studies using cells resuspended in deferrated buffer support this contention. Cells re- suspended in deferrated buffer consistently showed more uptake of radiolabelled iron than did cells resuspended in buffer containing higher levels of contaminating iron. With less exogenous, unlabelled ferric citrate formed, more ${ }^{55} \mathrm{Fe}$ from $\left[{ }^{55} \mathrm{Fe}\right]$ ferric citrate entered the cells.

The possibility exists that iron bound to citrate may also enter the cell by passing through a nonspecific porin which allows entry of both ferric citrate and citrate. As the ratio of citrate to iron increases, the competition between free and iron-bound citrate favours citrate. Hence, less ferric citrate enters the periplasm via this route. Increasing concentrations of citrate do not affect binding of $\left[{ }^{55} \mathrm{Fe}\right]$ ferric citrate to outer membranes, as these vesicles are metabolically inert.

Candidates for a ferric citrate receptor on the outer membranes of each cell type are the dominant 14 and $43 \mathrm{kDa}$ proteins. Sokol \& Woods (1983) reported a $14 \mathrm{kDa}$ protein on the outer membranes of $P$. aeruginosa which bound the ferric complex of pyochelin, but not ${ }^{59} \mathrm{FeCl}_{3}$. As the $43 \mathrm{kDa}$ protein is found in greatest concentration on the outer membranes of SSM-grown cells, which also bind more $\left[{ }^{55} \mathrm{Fe}\right] \mathrm{ferric}$ citrate than do the outer membranes of CSM- and SSM/CSM-grown cells, this protein could serve as a ferric-citrate-binding protein.

\section{References}

Ankenbauer, R., SRiyosachati, S. \& Cox, C. D. (1985). Effects of siderophores on the growth of Pseudomonas aeruginosa in human serum and transferrin. Infection and Immunity 49, 132-140.

ARCHIBALD, R. S. \& DEVoE, I. W. (1980). Iron acquisition by Neisseria meningitidis. Infection and Immunity 27, 322-334.

BRAUN, V. (1985). The iron transport systems of Escherichia coli. In The Enzymes of Biological Membranes, pp. 617-652. Edited by A. N. Martonosi. New York: Plenum Press.

Cox, C. D. (1980). Iron uptake with ferripyochelin and ferric citrate by Pseudomonas aeruginosa. Journal of Bacteriology 142, 581-587.

Frost, G. E. \& RosenBERG, H. (1973). The inducible citrate-dependent iron transport system in Escherichia coli K-12. Biochimica et Biophysica Acta 300, 90-101.

HOHNADEL, D. \& MEYER, J. M. (1988). Specificity of pyoverdinemediated iron uptake among fluorescent Pseudomonas strains. Journal of Bacteriology 170, 4865-4873.

Hussein, S., HaNTKE, K. \& BRaun, V. (1981). Citrate-dependent iron transport system in E. coli K-12. European Journal of Biochemistry 117, 431-437.

LAEMMLI, U. K. (1970). Cleavage of structural proteins during the assembly of the head of bacteriophage T4. Nature, London 227 , $680-685$.

LAWFORD, H. G. \& Williams, G. R. (1971). The transport of citrate and other tricarboxylic acids in two species of Pseudomonas. Biochemical Journal 123, 571-577.

Messenger, A. J. M. \& Ratledge, C. (1982). Iron transport in Mycobacterium smegmatis: uptake of iron from ferric citrate. Journal of Bacteriology 149, 131-135.

Meyer, J. M. \& ABdallah, M. A. (1978). The fluorescent pigment of Pseudomonas fluorescens: biosynthesis, purification and physicochemical properties. Journal of General Microbiology 107, 319-328.

Meyer, J. M., Mock, M. \& Abdallah, M. A. (1979). Effect of iron on the protein composition of the outer membrane of fluorescent pseudomonads. FEMS Microbiology Letters 5, 395-398. 
Meyer, J. M., Halle, F., Hohnadel, D., Lemanceau, P. \& RATEFIARIVELo, H. (1987). Siderophores of Pseudomonas - biological properties. In Iron Transport in Microbes, Plants, and Animals, pp. 189-205. Edited by G. Winkelmann, D. van der Helm \& J. B. Neilands. Weinheim: VCH Verlagsgesellschaft.

Mizuno, T. \& Kageyama, M. (1978). Separation and characterization of the outer membranes of Pseudomonas aeruginosa. Journal of Biochemistry 84, 179-191.

Simonson, C., TrivetT, T. \& DeVoe, I. W. (1981). Energy-dependent uptake of iron from citrate by isolated outer membranes of Neisseria meningitidis. Infection and Immunity 31, 547-553.

SoKol, P. A. \& Woods, D. E. (1983). Demonstration of an ironsiderophore binding protein in the outer membrane of Pseudomonas aeruginosa. Infection and Immunity 40, 665-669.
SPiro, T. G., Pape, L. \& Saltman, P. (1967a). The hydrolytic polymerization of ferric citrate. I. The chemistry of the polymer. Journal of the American Chemical Society 89, 5555-5559.

Spiro, T. G., PaPe, L. \& Saltman, P. (1967b). The hydrolytic polymerization of ferric citrate. II. The influence of excess citrate. Journal of the American Chemical Society 89, 5559-5562.

WAGEGG, W. \& BRAUN, V. (1981). Ferric citrate transport in Escherichia coli requires outer membrane receptor protein FecA. Journal of Bacteriology 145, 156-163.

WeIssBach, A. \& HuRwITZ, J. (1959). The formation of 2-keto-3deoxyheptonic acid in extracts of Escherichia coli B. Journal of Biological Chemistry 234, 705-709.

WiNKELMANN, G. (1979). Surface iron polymers and hydroxy acids. A model of iron supply to sideramine-free fungi. Archives of Microbiology 121, 43-51. 